\title{
The Role of Continuous Education Programs Organized by Saudi Universities in Literacy-A Case Study of King Saud University
}

\author{
Haya Saad Abdulla Al Rawaf ${ }^{1}$, Azza Khalil Abdel Fattah ${ }^{1,2}$, Fadia Yousif Abdel Megeid ${ }^{3}$, \\ Rania Mohammed Aziz Nazmy ${ }^{1}$, Sarah Nasser Alarifi ${ }^{1}$ \& Hind Sulaiman Al Sulaihm ${ }^{1}$ \\ ${ }^{1}$ College of Education, King Saud University, Riyadh, Saudi Arabia \\ ${ }^{2}$ Ain Shams University, Cairo, Egypt \\ ${ }^{3}$ Helwan University, Cairo, Egypt \\ Correspondence: Haya Saad Abdulla Al Rawaf, Adult and Continuous Education Department, College of \\ Education, King Saud University, Prince Turkey street, Exit 2, Riyadh, Saudi Arabia. E-mail: \\ prof.hayarawwaf@gmail.com
}

Received: September 28, 2016

Accepted: November 2, $2016 \quad$ Online Published: March 30, 2017

doi:10.5539/ies.v10n4p187

URL: https://doi.org/10.5539/ies.v10n4p187

This is a research project that was supported by a grant from the Research Centre for the Humanities, Deanship of Scientific Research at King Saud University 2016.

\begin{abstract}
This study aims at highlighting the role of Continuous Education Programs at the Saudi Universities in Religious, Social, and Health Literacy; King Saud University was taken as an example. To achieve the goals of the study two questionnaires were distributed among two samples from King Saud University; (101) of students, and (9) of continuous education centers' directors. Results showed that continuous education programs presented in religious awareness development do not contribute sufficiently in developing them. However; continuous education programs have favorable role in community's social culturing. Also, continuous education programs contribute, at medium degree, in community's health culturing. On the other hand; people in charge agree that the investment revenue in financing continuous education programs is minor as well as financing offered by the University. In light of the study results, the researchers recommended paying more attention to present more continuous education programs of concern as to individuals' needs through cooperation with the research center in the University to perform survey studies targeted to define the individuals' needs in terms of religious, social and health issues.
\end{abstract}

Keywords: continuous education, literacy, Saudi Arabia, religious, social, health, King Saud University

\section{Introduction and Background}

Continuous education is considered as a particular education in terms of enabling concerned parties to compete within international economy to decrease the poverty rates in their areas. The developing countries fail to support education opportunities since the gap in building skills and using modern techniques shall continue to expand and grow between developed and developing countries (Putnam, 2001). Continuous education is not limited to adults, but it includes children at all age stages. The continuous education is based on two philosophies; advanced philosophy, which is based on transferring the cultural and social infrastructures to enhance the social changes and offering the learner practical knowledge and problem solving skills to reform their communities. The pioneer of this philosophy-John Dewi-assured the continuous education importance as it aims at achieving all the learners' needs. On the other hand, the traditional philosophy believes in developing the mind's intellectual capacities to prepare an individual learner for intellectual, moral and spiritual sphere (Kumar, 2012).

Illiteracy is one of the important issues that face the educational, cultural, political, health and environmental challenges. It represents a dilemma, which faces the worldwide countries in general, and the Arab countries in particular. As a reality, there are 7750 million illiterates around the world (Hammer, 2010). Such issue affects vocational, social and financial status of individuals. Many studies tackled the negative effect of illiteracy; for example the results of The Australian Industry Group's study (2010); which was conducted on 338 companies, where 65,000 employees are working in; showed that $75 \%$ out of the employees suffer from illiteracy and thus 
they did not acquire promotions in their work. The foregoing worked to force employers to waiver some standards in promotions and admissions and replacement. This, indeed, impacts the work productivity, and the study therefore, addressed recommendations to raise the illiterate employees' efficiency through specific literate programs.

Continuous education programs at universities should play an obvious role in assisting the individuals to develop themselves, keeping up all new changes, updates and taking part in fighting all what impede community development; such as all types of illiteracy. The foregoing inspired universities to establish community service centers and continuous education that are engaged in edification through lectures which tackle social, economic, political; local, regional and international subjects, in addition to other subjects of concern as to individual and family problems, as well as scientific and technological subjects. The programs set out by the universities are variable such as languages, secretarial, science basis, and psychological health and auto mechanics programs (Said, 1990).

Furthermore, religious education occupies distinguished stand and special interest by the community individuals, at some communities. The foregoing worked to lade religious edification and eliminate religious illiteracy's burden over universities through programs and strategies conducted by specialists in religious sphere. These programs aim to treat the contemporary issues, renew the contemporary religious speech, correcting the faulty religious thoughts, all of which worked to eliminate the extremist religious thought. The most important means that contribute in circulating the extremist ideology are; Internet, social interconnection means, extremists' key leaders' advice, and religious strict sermons and lectures.

From this point, the programs addressed by the university and targeted broadcasting programs are considered of great influence as to disregard extremism. Fuad (1998) referred to high portion of listeners of such programs among university students in Egypt. The study of Ghareeb (2005) has supported this conclusion in terms of a program which is transmitted via Satellite channels (Read Channel) which tackles religious subjects. Besides, Al Sallal (2012) observed the impact of the Kuwaiti satellite channels' role in enhancing citizenship issue and disregard extremism among Kuwaiti Youth and Arabs' original values as well. He noticed that such channels work moderately to deepening Islam accurate and continuous values moderately.

In our Arab communities we can notice individuals' needs as to know-how in respect of subjects which are not covered, or covered at insufficient manner, in the fundamental education. The most important subjects that the communities may contribute therein are to offer health education for its individuals. Health education represents important sphere that operates to realize health concept through publicizing health awareness and culture. Further it seeks providing individuals with accurate health information in parallel with urging them to adopt positive behaviors. Moreover, the forgoing leads to translate the familiar facts into modes and healthy behaviors, at the individual and community levels, by using modern methods of education (Rashad, 2000; Abdel-Majeed 2012). Therefore, a number of studies tackled the importance of publicizing the health awareness among various communities. Such studies referred to low awareness and health culture among elderly people. For example; Terry and Woodroffe's (2013) study requires intervention to raise the health culture level among community. Such community category lacks health culture that causes increasing emergency cases in hospitals, weak acceptance to preventive interventions, consequently death cases increase. Loos (2013) noticed shortages in Benchmarks at some communities in terms of health culture; he conducted a study to find out the effect of parents' knowledge on how to deal with children fever on reducing emergency cases in hospitals.

Social educating scope and individuals' efficiency to learn life and vocational skills are concerned as major communicative programs among societies all over the world. Baro (2013) discussed the necessity to educate students with the continuous education skill independently before graduating from University. In order to prepare the student awareness of Informative knowledge, he/she should have the ability to determine when they need such information, and have the ability to determine, evaluate, and use these needed information effectively.

Al Saadat (2004) figured out how continuous education and community service center at the Technological College in Al Ihsaa, could meet community and individuals needs from the teaching committee's point of view. Such study outcomes revealed that community service center and continuous education in that college meet community and individuals' needs through facilitating registration procedures in educational and training programs. On the other hand, the center awareness of the community needs facilitates planning for programs in a way to correspond with community and individuals domains. Moreover, the industrial training is addressed by the center to community individuals depending on local market demands. Besides, Belonozhko and Khitu (2006) conducted a study in which a selected sample from two groups; Americans and Russians, revealed that 109 persons are registered in various programs of community service in Phoenix University and 102 persons from 
Russia are registered in community service programs in TSUPG University. The main motive of both groups was to acquire knowledge.

Kunstler (2000) prepared a study on FRESH project for old people health, which was applied jointly by governmental university and local center, serving old black people and persons of Latin origins. This program was designed to supply fixed training consisting of 10 recreational sessions and swimming programs by using the college facilities. For the purpose of encouraging old people to participate in fitness activities and expanding their engagement in recreational programs connected therewith, certain applications and planning strategies were followed. Also an evaluation was carried out by participants and project team. Old people said that they crossed beyond their original goals, which urged them to participate therein, and two third of the selected sample participated, after the experiment.

From this point the current study tried to clarify the important role of continuous education centers at Saudi Universities in general and at King Saud University as a model. It highlights their importance in raising health awareness, religious culture, and occupational and personal development through presented programs. These programs are adapted to satisfy the served local environment needs, designing projects based on such needs, raising the community individuals' awareness in a way to prepare such programs to work as preventive factor against various environmental, cultural and economic risks.

\subsection{Problem}

Illiteracy witnesses an increasing domain during these days. The exerted efforts employed in facing illiteracy with all its financial and human capacities did not have room except for $2 \%$ of the current balance of Illiterates in The Arab World. On the other hand, those who passed illiteracy programs do not exceed $1 \%$ thereof per annum. Notwithstanding the set out strategies on both levels; global and Arab, to eliminate the illiteracy, but such strategies are still under trapped actions and decisions which work to disrupt their required role (Al Rawaf, 2008).

Whereas the Universities are an effective changes' mean, they work to offer assistance in forming a scientific view to prepare people for accepting changes within community philosophy, value and culture. Such job sprints from the fact that the university ought to represent a scientific and cultural core within the community. That role could be played through opening to the local community, strengthening links therewith, offering consultations, contributing in solving its problems, helping the community to employ its natural resources through supplying trained manpower. Thus the university could not isolate itself away from the current social problems, but on the contrary, it has to develop its services offered to public outside the university campus (Miqdadi, 2006)

Starting from this point, many developed countries worked to develop its universities to serve its communities. For example; since three decades, four universities in California-United States of America started offering services to the local communities such as consultations, continuous educational programs, conducting various courses for learners, urging teaching members to establish fruitful relations with the community. On the other hand, in South Korea the Ministry of Health and some charitable societies with a number of universities offered health and social care programs for disabled individuals and elderly people. More over; Polytechnics in Singapore started to present programs connected with community service programs; i.e. Electrical, marine Engineering and else (Ammar, 2009).

In the Arab world, various studies such as a study prepared by (Rawwaf, 2014), handled the absence of planning as to continuous education programs in the Arab universities to serve their communities. This absence of such continuous programs worked, indeed, to weakening the communities' development and knowledge production. The researcher recommends strongly the need to enforce continuous education programs within its all modes at Saudi universities, which will be reflected positively to the Saudi society in different everyday life's needs.

Since the cognition explosion accelerated all over the world, and Illiteracy causes a dangerous damage in religious, health and social meanings among societies, this research tries to identify and highlight the role of universities through continuous education programs in educating the Saudi societies in terms of religious, health and social aspects.

\subsection{Objectives}

The main objective of the current study is to identify the continuous education programs' role offered by the Universities to raise the illiterates' awareness about religious, health and social culturing during the knowledge revolution era. A number of minor objectives are derived from the main objective of the study:

1) Identifying continuous education programs' real role, offered at King Saud University in terms of religious culturing. 
2) Identifying continuous education programs' real role, offered at King Saud University in terms of social culturing.

3) Identifying Continuous education programs' real role, offered at King Saud University in terms of Health culturing.

4) Detecting challenges, which face continuous education program at King Saud University.

\subsection{Questions}

The main question raised in this study is:

What is the continuous education program's role, offered by the Saudi Universities in terms of religious, social and health culturing (King Saudi University as a sample)?

The following minor questions are derived from the above question:

1) What is the continuous education program's role at King Saud University as to religious culturing?

2) What is the continuous education program's role at King Saud University as to social culturing?

3) What is the continuous education program's role at King Saud University as to Health culturing?

4) What are the challenges that face the continuous education program at King Saud University?

\subsection{Study Importance}

The research importance is due to the following aspects:

1) Continuous education and respective programs are important in observing religious, social and health culturing.

2) This study may be beneficial as to universities \& community organizations in terms of cooperation and partnership to offer services to the community.

3) The study outcomes may work to draw a model that may assist the universities to activate social and health culturing through continuous education programs.

\subsection{Study Terms}

1) Role: means continuous education programs role at Saudi Universities handling religious, social and health culturing

2) Religious culturing: is the teaching religious matters in due course based on Qur'an and Authentic Sayings (Hadiths) of the Prophet Muhammad (PBUH).

3) Social culturing: raising children on terms of good communication to avoid the miss-use of communicative means.

4) Health culturing: means many health care matters such as bad nutrition habits, fat diseases, Herbals, teeth decay, etc.

\section{Method}

\subsection{Methodology}

To achieve the goals of the study, the researchers followed the descriptive survey. The survey tries to find out the reality of the continuous education programs presented through King Saud University and their role in religious, social and health culturing. In addition, the survey is used to identify the obstacles that face these continuous education programs at the Saudi Universities. The results of the survey may help to set out suitable recommendations to develop the continuous education programs at the Saudi Universities in general and King Saud University in specific.

\subsubsection{Community}

The study community is consisted of (980) undergraduate students from the colleges of King Saud University. Also it consisted of (12) personnel employed in The Continuous Education Center of King Saud University.

\subsubsection{Sample}

A random sample of (101) students was chosen from King Saud University; (63) students represented the Human Colleges-62.38\% of the total study sample-; (38) students represented the Scientific Colleges $-37.62 \%$ of the total study sample. Master degree students were (89) rated at $88.12 \%$ of the total number of the sample while Doctorate degree students were 12 , at $11.88 \%$ of total selected sample. As to gender, males were 35 at $34.65 \%$ 
while females were 66 rated at $65.35 \%$

In addition, a sample of (9) managers and employees in the Continuous Education Center of King Saud University was chosen randomly, as well.

\subsubsection{Tools}

Researches used two questionnaires:

- A questionnaire distributed to graduate students, which include: religious culturing, social culturing and health culturing.

- A questionnaire distributed to managers and employees of continues education centers, which include: expenditure, participation and attendance and management.

\subsubsection{Internal Reliability}

The Internal reliability of the first questionnaire was calculated by applying it on all the sample's members. Pearson correlation coefficient was calculated between scores for each phrase and total domain score, and there was correlation coefficient between total score, for each domain of the questionnaire, and total questionnaire score. For such purpose the researchers used SPSS program to analyze data. From Pearson correlation coefficient in the four domains the researchers noticed a correlation between the phrases in the domain which was significant at $(\alpha \geq 0.01)$. It was noticed that the total score of each domain is correlated with total score domain of the questionnaire which was significant at $(\alpha \geq 0.01)$.

In addition, the Internal reliability of the second questionnaire was calculated. It was addressed to the workers in charge at the continuous Education Center of King Saud University. Pearson correlation coefficient was calculated between the score of each phrase and the total domain's score that it belongs to. Also, the correlation coefficient was calculated between the total score of each domain and the total score of the questionnaire. It was clear from Pearson correlation coefficient in the four domains that there is a correlation among all phrases in the domain, which was significant at $(\alpha \geq 0.01)$.

\subsubsection{Validity}

The $1^{\text {st }}$. questionnaire's validity was calculated through applying it on all the sample's students using Cronbach Alpha coefficient. The questionnaire's validity was very high; Cronbach Alpha was (0.94-0.95). On the other hand, Cronbach Alpha coefficient of the whole questionnaire was (0.97). These numbers prove the questionnaire's validity.

The second questionnaire was prepared for the workers of the Continuous Education Center. Its validity was calculated after applying the questionnaire on all the sample's members Cronbach Alpha coefficient was (0.90, 096). This result shows a high validity of the questionnaire.

\subsubsection{Data Analysis}

Different statistical methods were used to achieve the goals of the current study:

- Frequencies and percentages to describe sample individuals.

- Standard Deviation to identify individuals' responses deviation extent for each phrase of the questionnaire Domains' phrases. Standard deviation clarifies distraction in the individuals' responses on each phrase, as far as the value is close to zero, the responses are concentrated and distraction falls.

- Pearson Correlation Coefficient to measure the questionnaire reliability.

- Cronbach Alpha Coefficient to measure the questionnaire's validity.

\section{Results and Discussion}

This portion of the study is dedicated to present the results of the study. It contains answers of the study questions:

\subsection{Question \#1: What Is the Continuous Educational Program's Role at King Saud University in Terms of Religious Culturing?}

Results stated that the majority of the sample individuals do not know about such programs representing $81.51 \%$ out of study sample. However, $70.22 \%$ of program attendee indicated that the program did not satisfy their wish as to knowledge on religious causes, enhancing moderate medium thinking and defining entities who may offer help in terms of religious problems. Table 1 shows the frequencies, percentages, and standard deviation of the sample's individuals in terms of the role of continuous education in religious education at King Saud University. 
Table 1. Frequencies, Percentages, standard deviation of the sample's members in terms of continuous education role in religious culturing at King Saud University

\begin{tabular}{|c|c|c|c|c|c|c|c|c|}
\hline Item & Phrase & $\begin{array}{l}\text { Affirm. } \\
\text { Agree }\end{array}$ & Agree & $\begin{array}{l}\text { Don't } \\
\text { know }\end{array}$ & $\begin{array}{l}\text { Don't } \\
\text { agree }\end{array}$ & $\begin{array}{l}\text { Affirm. } \\
\text { Disagree }\end{array}$ & $\begin{array}{l}\text { Standard } \\
\text { deviation }\end{array}$ & Frequencies \\
\hline 1 & $\begin{array}{l}\text { University presents religious awareness } \\
\text { development on the woman role in the } \\
\text { community. }\end{array}$ & $\begin{array}{c}11 \\
10.89\end{array}$ & $\begin{array}{c}19 \\
18.81\end{array}$ & $\begin{array}{c}53 \\
52.48\end{array}$ & $\begin{array}{c}11 \\
10.89\end{array}$ & $\begin{array}{c}7 \\
6.93\end{array}$ & 1 & 3 \\
\hline 2 & $\begin{array}{l}\text { I prepared programs in the University that } \\
\text { enforce intellectual security among } \\
\text { community individuals. }\end{array}$ & $\begin{array}{c}8 \\
7.92\end{array}$ & $\begin{array}{c}28 \\
27.72\end{array}$ & $\begin{array}{c}33 \\
32.67\end{array}$ & $\begin{array}{c}19 \\
18.81\end{array}$ & $\begin{array}{c}13 \\
12.87\end{array}$ & 1.14 & 9 \\
\hline 3 & $\begin{array}{l}\text { The University contains research chairs } \\
\text { enhancing the awareness sector in religious } \\
\text { culturing among community individuals } \\
\text { and linking them to contemporary causes }\end{array}$ & $\begin{array}{c}11 \\
10.89\end{array}$ & $\begin{array}{c}31 \\
30.69\end{array}$ & $\begin{array}{c}49 \\
48.51\end{array}$ & $\begin{array}{c}5 \\
4.95\end{array}$ & $\begin{array}{c}5 \\
4.95\end{array}$ & 0.93 & 1 \\
\hline 4 & $\begin{array}{l}\text { University offers religious lectures serving } \\
\text { the community and replies on their } \\
\text { religious inquires. }\end{array}$ & $\begin{array}{c}10 \\
99.9\end{array}$ & $\begin{array}{c}22 \\
21.78\end{array}$ & $\begin{array}{c}51 \\
50.5\end{array}$ & $\begin{array}{c}9 \\
8.91\end{array}$ & $\begin{array}{c}9 \\
8.91\end{array}$ & 1.02 & 4 \\
\hline 5 & $\begin{array}{l}\text { University holds courses, seminars on } \\
\text { Jehad concept, basis and types. }\end{array}$ & $\begin{array}{c}8 \\
7.92 \\
\end{array}$ & $\begin{array}{c}3 \\
2.97 \\
\end{array}$ & $\begin{array}{c}63 \\
62.38 \\
\end{array}$ & $\begin{array}{c}13 \\
12.87 \\
\end{array}$ & $\begin{array}{c}14 \\
13.86 \\
\end{array}$ & 1 & 13 \\
\hline 6 & $\begin{array}{l}\text { University prepared programs that help in } \\
\text { highlighting the moderate thinking. }\end{array}$ & $\begin{array}{c}7 \\
6.93 \\
\end{array}$ & $\begin{array}{c}17 \\
16.83 \\
\end{array}$ & $\begin{array}{c}49 \\
48.51\end{array}$ & $\begin{array}{c}18 \\
17.82 \\
\end{array}$ & $\begin{array}{l}10 \\
9.9\end{array}$ & 1.01 & 11 \\
\hline 7 & $\begin{array}{l}\text { University launches training courses to } \\
\text { develop Jurisprudence of calamity. }\end{array}$ & $\begin{array}{c}5 \\
4.95 \\
\end{array}$ & $\begin{array}{c}6 \\
5.94 \\
\end{array}$ & $\begin{array}{c}74 \\
73.27 \\
\end{array}$ & $\begin{array}{l}10 \\
9.9 \\
\end{array}$ & $\begin{array}{c}6 \\
5.94 \\
\end{array}$ & 0.77 & 10 \\
\hline 8 & $\begin{array}{l}\text { University strategy is to present integrated } \\
\text { scientific program to release religious } \\
\text { culturing among community organizations }\end{array}$ & $\begin{array}{c}9 \\
8.91\end{array}$ & $\begin{array}{c}20 \\
19.8\end{array}$ & $\begin{array}{c}53 \\
52.48\end{array}$ & $\begin{array}{c}11 \\
10.89\end{array}$ & $\begin{array}{c}8 \\
7.92\end{array}$ & 0.99 & 7 \\
\hline 9 & $\begin{array}{l}\text { University presents programs to link } \\
\text { applied sciences with religious studies. }\end{array}$ & $\begin{array}{c}7 \\
6.93 \\
\end{array}$ & $\begin{array}{c}22 \\
21.78\end{array}$ & $\begin{array}{c}49 \\
48.51\end{array}$ & $\begin{array}{c}17 \\
16.83 \\
\end{array}$ & $\begin{array}{c}6 \\
5.94 \\
\end{array}$ & 0.95 & 8 \\
\hline 10 & $\begin{array}{l}\text { Attending religious courses conducted in } \\
\text { the University brought me aware of the } \\
\text { family role importance in community } \\
\text { development. }\end{array}$ & $\begin{array}{c}17 \\
16.83\end{array}$ & $\begin{array}{c}22 \\
21.78\end{array}$ & $\begin{array}{c}43 \\
42.57\end{array}$ & $\begin{array}{c}12 \\
11.88\end{array}$ & $\begin{array}{c}7 \\
6.93\end{array}$ & 1.1 & 2 \\
\hline 11 & 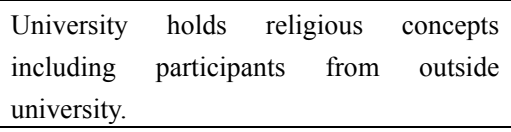 & $\begin{array}{c}7 \\
6.93\end{array}$ & $\begin{array}{c}20 \\
19.8\end{array}$ & $\begin{array}{c}58 \\
57.43\end{array}$ & $\begin{array}{c}10 \\
9.9\end{array}$ & $\begin{array}{c}6 \\
5.94\end{array}$ & 0.9 & 5 \\
\hline 12 & $\begin{array}{l}\text { I benefit of English courses conducted in } \\
\text { the University in terms of releasing } \\
\text { religious culturing. }\end{array}$ & $\begin{array}{c}8 \\
7.92\end{array}$ & $\begin{array}{c}15 \\
14.85\end{array}$ & $\begin{array}{c}44 \\
43.56\end{array}$ & $\begin{array}{c}22 \\
21.78\end{array}$ & $\begin{array}{c}12 \\
11.88\end{array}$ & 1.07 & 12 \\
\hline 13 & $\begin{array}{l}\text { I read some releases issued by publishing } \\
\text { houses after attending seminar in the } \\
\text { university where religious men were } \\
\text { hosted. }\end{array}$ & $\begin{array}{c}7 \\
7.93\end{array}$ & $\begin{array}{c}7 \\
6.93\end{array}$ & $\begin{array}{c}50 \\
49.5\end{array}$ & $\begin{array}{c}25 \\
24.75\end{array}$ & $\begin{array}{c}12 \\
11.88\end{array}$ & 1 & 15 \\
\hline 14 & $\begin{array}{l}\text { I identified entities who offer aid in } \\
\text { religious inquires through seminars at } \\
\text { university }\end{array}$ & $\begin{array}{c}6 \\
59.94\end{array}$ & $\begin{array}{c}14 \\
13.86\end{array}$ & $\begin{array}{c}46 \\
45.54\end{array}$ & $\begin{array}{c}22 \\
21.78\end{array}$ & $\begin{array}{c}13 \\
12.87\end{array}$ & 1.04 & 13 \\
\hline 15 & $\begin{array}{l}\text { University supports teaching learners to } \\
\text { hold courses in legal sciences presented to } \\
\text { individuals. }\end{array}$ & 8.91 & 9.0 & 69.31 & 7.92 & 3.96 & & \\
\hline & General Average & & & & & & 0.98 & \\
\hline
\end{tabular}

Results in Table 1 confirm that most of Standard Deviation's values; as to continuous education programs role in the Universities, are limited between: $(0.77,1.14)$. The least standard deviation was on the phrase (The University launches training courses that develop awareness in Jurisprudence of calamity). This refers that the sample individuals agreed at major level on religious Muftis legal advice. Whilst subjects that urge for individual Jurisprudence, scrutiny \& mental comparison with contemporary causes did not acquire high agreement rates 
among the sample individuals.

\subsection{Question \#2: What Is the Continuous Educational Program's Role at King Saud University in Terms of Social Culturing?}

To answer this question, frequencies, percentages, and standard deviations of the sample's members in terms of continuous education role in social culturing at King Saud University were calculated and analyzed. Table 2 shows the results:

Table 2. Frequencies, percentages, standard deviation of the sample's members in terms of continuous education role in social culturing at King Saud University

\begin{tabular}{|c|c|c|c|c|c|c|c|c|}
\hline Item & Phrase & $\begin{array}{c}\text { Affirm. } \\
\text { Agree }\end{array}$ & Agree & $\begin{array}{l}\text { Don't } \\
\text { know }\end{array}$ & $\begin{array}{l}\text { Don't } \\
\text { agree }\end{array}$ & $\begin{array}{l}\text { Affirm. } \\
\text { Disagree }\end{array}$ & $\begin{array}{l}\text { Standard } \\
\text { deviation }\end{array}$ & Sequence \\
\hline 1 & $\begin{array}{l}\text { University holds programs to support } \\
\text { self-development skills (dealing with } \\
\text { others, debate skills. }\end{array}$ & $\begin{array}{c}35 \\
34.65\end{array}$ & $\begin{array}{c}45 \\
44.55\end{array}$ & $\begin{array}{c}15 \\
14.85\end{array}$ & $\begin{array}{c}5 \\
4.95\end{array}$ & $\begin{array}{c}1 \\
0.99\end{array}$ & 0.89 & 1 \\
\hline 2 & $\begin{array}{l}\text { University holds cultural programs that } \\
\text { help in understanding family disputes and } \\
\text { methods of solving problems. }\end{array}$ & $\begin{array}{c}14 \\
13.86\end{array}$ & $\begin{array}{c}33 \\
32.67\end{array}$ & $\begin{array}{c}42 \\
41.58\end{array}$ & $\begin{array}{c}11 \\
10.89\end{array}$ & $\begin{array}{c}1 \\
0.99\end{array}$ & 0.9 & 8 \\
\hline 3 & $\begin{array}{l}\text { University holds awareness and parental } \\
\text { programs in childhood stage. }\end{array}$ & $\begin{array}{c}13 \\
12.87 \\
\end{array}$ & $\begin{array}{c}23 \\
22.77 \\
\end{array}$ & $\begin{array}{c}53 \\
52.48 \\
\end{array}$ & $\begin{array}{c}11 \\
10.89 \\
\end{array}$ & $\begin{array}{c}1 \\
0.99 \\
\end{array}$ & 0.88 & 10 \\
\hline 4 & $\begin{array}{l}\text { I identified the entities who may offer aid } \\
\text { in childhood stage }\end{array}$ & $\begin{array}{c}9 \\
8.91\end{array}$ & $\begin{array}{c}17 \\
16.83\end{array}$ & $\begin{array}{c}49 \\
48.51\end{array}$ & $\begin{array}{c}18 \\
17.82\end{array}$ & $\begin{array}{c}8 \\
7.92\end{array}$ & 1.01 & 21 \\
\hline 5 & $\begin{array}{l}\text { I identified entities who may offer aid in } \\
\text { teenage through university programs. }\end{array}$ & $\begin{array}{c}8 \\
7.92 \\
\end{array}$ & $\begin{array}{c}23 \\
22.77 \\
\end{array}$ & $\begin{array}{c}44 \\
43.56 \\
\end{array}$ & $\begin{array}{c}18 \\
17.82 \\
\end{array}$ & $\begin{array}{c}8 \\
7.92 \\
\end{array}$ & 1.02 & 20 \\
\hline 6 & $\begin{array}{l}\text { University holds programs to develop } \\
\text { graduates skills to join jobs. }\end{array}$ & $\begin{array}{c}32 \\
31.68 \\
\end{array}$ & $\begin{array}{r}38 \\
37.62 \\
\end{array}$ & $\begin{array}{c}25 \\
24.75 \\
\end{array}$ & $\begin{array}{c}4 \\
3.96 \\
\end{array}$ & $\begin{array}{c}2 \\
1.98 \\
\end{array}$ & 0.95 & 2 \\
\hline 7 & $\begin{array}{l}\text { University holds cultural programs on } \\
\text { child rights, disabled and supporters. }\end{array}$ & $\begin{array}{c}12 \\
11.88 \\
\end{array}$ & $\begin{array}{c}29 \\
28.71 \\
\end{array}$ & $\begin{array}{c}47 \\
46.53 \\
\end{array}$ & $\begin{array}{c}7 \\
6.93 \\
\end{array}$ & $\begin{array}{c}6 \\
5.94 \\
\end{array}$ & 0.98 & 12 \\
\hline 8 & $\begin{array}{l}\text { The University holds cultural programs on } \\
\text { women legal rights. }\end{array}$ & $\begin{array}{l}10 \\
9.9\end{array}$ & $\begin{array}{c}25 \\
24.75 \\
\end{array}$ & $\begin{array}{c}54 \\
53.47\end{array}$ & $\begin{array}{c}7 \\
6.93 \\
\end{array}$ & $\begin{array}{c}7 \\
4.95\end{array}$ & 0.92 & 16 \\
\hline 9 & $\begin{array}{l}\text { The University holds cultural programs on } \\
\text { handicaps' rights. }\end{array}$ & $\begin{array}{r}10 \\
9.9 \\
\end{array}$ & $\begin{array}{c}26 \\
25.74 \\
\end{array}$ & $\begin{array}{c}52 \\
51.49 \\
\end{array}$ & $\begin{array}{c}9 \\
8.91\end{array}$ & $\begin{array}{c}4 \\
3.96 \\
\end{array}$ & 0.91 & 15 \\
\hline 10 & $\begin{array}{l}\text { I identified entities who support people of } \\
\text { special needs through university programs. }\end{array}$ & $\begin{array}{c}9 \\
8.91 \\
\end{array}$ & $\begin{array}{c}21 \\
20.79 \\
\end{array}$ & $\begin{array}{c}48 \\
47.52 \\
\end{array}$ & $\begin{array}{c}16 \\
15.84 \\
\end{array}$ & $\begin{array}{c}7 \\
6.93 \\
\end{array}$ & 1 & 18 \\
\hline 11 & $\begin{array}{lrrr}\begin{array}{l}\text { University } \\
\text { tackling folds }\end{array} \text { Cultural programs } \\
\text { management. }\end{array}$ & $\begin{array}{r}10 \\
9.9\end{array}$ & $\begin{array}{c}27 \\
26.73\end{array}$ & $\begin{array}{c}51 \\
50.5\end{array}$ & $\begin{array}{c}9 \\
8.91\end{array}$ & $\begin{array}{c}4 \\
3.96\end{array}$ & 0.91 & 14 \\
\hline 12 & $\begin{array}{l}\text { University presents Cultural programs to } \\
\text { develop hobbies and time management } \\
\text { arts. }\end{array}$ & $\begin{array}{c}19 \\
18.81\end{array}$ & $\begin{array}{c}52 \\
51.49\end{array}$ & $\begin{array}{c}25 \\
24.75\end{array}$ & $\begin{array}{c}4 \\
3.96\end{array}$ & $\begin{array}{c}1 \\
0.99\end{array}$ & 0.81 & 4 \\
\hline 13 & $\begin{array}{l}\text { University participates in illiteracy } \\
\text { programs with concerned community } \\
\text { organizations. }\end{array}$ & $\begin{array}{c}6 \\
5.94\end{array}$ & $\begin{array}{c}16 \\
15.84\end{array}$ & $\begin{array}{c}69 \\
68.32\end{array}$ & $\begin{array}{c}9 \\
8.91\end{array}$ & $\begin{array}{c}1 \\
0.99\end{array}$ & 0.71 & 17 \\
\hline 14 & $\begin{array}{l}\text { University holds cultural programs to raise } \\
\text { awareness as to voluntarily work. }\end{array}$ & $\begin{array}{c}26 \\
25.74 \\
\end{array}$ & $\begin{array}{c}32 \\
31.68 \\
\end{array}$ & $\begin{array}{c}34 \\
33.66 \\
\end{array}$ & $\begin{array}{c}6 \\
5.94 \\
\end{array}$ & $\begin{array}{c}3 \\
2.97 \\
\end{array}$ & 1.01 & 5 \\
\hline 15 & $\begin{array}{l}\text { University holds cultural programs on } \\
\text { competitive projects, methods, and } \\
\text { supportive entities. }\end{array}$ & $\begin{array}{c}17 \\
16.83\end{array}$ & $\begin{array}{c}37 \\
36.63\end{array}$ & $\begin{array}{c}39 \\
38.61\end{array}$ & $\begin{array}{c}5 \\
4.95\end{array}$ & $\begin{array}{c}3 \\
2.97\end{array}$ & 0.93 & 7 \\
\hline 16 & $\begin{array}{l}\text { University holds training programs to } \\
\text { develop digital skills (computer arts). }\end{array}$ & $\begin{array}{c}24 \\
23.76\end{array}$ & $\begin{array}{c}50 \\
49.5\end{array}$ & $\begin{array}{c}23 \\
22.77\end{array}$ & $\begin{array}{c}3 \\
2.97\end{array}$ & $\begin{array}{c}1 \\
0.99\end{array}$ & 0.82 & 3 \\
\hline 17 & $\begin{array}{l}\text { University holds training programs on } \\
\text { English language. }\end{array}$ & $\begin{array}{c}23 \\
22.77\end{array}$ & $\begin{array}{c}37 \\
36.63\end{array}$ & $\begin{array}{c}29 \\
28.71\end{array}$ & $\begin{array}{c}6 \\
5.94\end{array}$ & $\begin{array}{c}6 \\
5.94\end{array}$ & 1.08 & 6 \\
\hline
\end{tabular}




\begin{tabular}{|c|c|c|c|c|c|c|c|c|}
\hline 18 & $\begin{array}{l}\text { University holds seminars hosting writers } \\
\text { to discuss their literal books }\end{array}$ & $\begin{array}{c}12 \\
11.88\end{array}$ & $\begin{array}{c}34 \\
33.66\end{array}$ & $\begin{array}{c}42 \\
41.58\end{array}$ & $\begin{array}{c}9 \\
8.91\end{array}$ & $\begin{array}{c}4 \\
3.96\end{array}$ & 0.95 & 9 \\
\hline 19 & $\begin{array}{l}\text { University holds seminars to discuss most } \\
\text { recent edits of press houses to improve } \\
\text { community knowledge. }\end{array}$ & $\begin{array}{c}12 \\
11.88\end{array}$ & $\begin{array}{c}26 \\
25.74\end{array}$ & $\begin{array}{c}51 \\
50.5\end{array}$ & $\begin{array}{c}7 \\
6.93\end{array}$ & $\begin{array}{c}5 \\
4.95\end{array}$ & 0.95 & 13 \\
\hline 20 & $\begin{array}{l}\text { University holds seminars to release } \\
\text { psychological culture, most common } \\
\text { Psychological \&educational problems. }\end{array}$ & $\begin{array}{c}9 \\
8.91\end{array}$ & $\begin{array}{c}30 \\
29.7\end{array}$ & $\begin{array}{c}52 \\
51.49\end{array}$ & $\begin{array}{c}8 \\
7.92\end{array}$ & $\begin{array}{c}2 \\
1.98\end{array}$ & 0.83 & 11 \\
\hline 21 & $\begin{array}{l}\text { I became aware of entities that offer help } \\
\text { on above problems through University } \\
\text { programs }\end{array}$ & $\begin{array}{c}7 \\
6.93\end{array}$ & $\begin{array}{c}21 \\
20.79\end{array}$ & $\begin{array}{c}52 \\
51.49\end{array}$ & $\begin{array}{c}14 \\
13.86\end{array}$ & $\begin{array}{c}7 \\
6.93\end{array}$ & 0.95 & 19 \\
\hline
\end{tabular}

Results of the second question which are presented in Table 2 show the fact that majority of the study sample do not know about Social culturing programs which are presented at King Saud University. Those who do not know are rated at $42.24 \%$ while the approvals are rated at $28.77 \%$ of the attendants. The disapprovals rate was $12.54 \%$. The foregoing refers to failure in declaring such programs in due course. In the same time those who attended were satisfied of such programs' contents and concepts. The least rate was unsatisfied as to the program contents. This assured the idea of Baro (2013) as he assured that the most programs that acquired the individuals' interest and concern are the social culturing programs since they are enabling them to learn many life skills. The reason behind satisfaction's high rates on social culturing programs compared with religious culturing is the relative rise of the religious culture in the community of Saudi Arabia which worked to reduce satisfaction rates on presented programs; especially such programs did not offer new subjects or treating contemporary causes on the light of religion principles.

\subsection{Question \#(3): What Is the Continuous Educational Program's Role at King Saud University in Terms of Health Culturing?}

To answer this question, frequencies, percentages, and standard deviations of the sample's members in terms of continuous education role in health culturing at King Saud University were calculated and analyzed. Table 3 shows the results:

Table 3. Frequencies, percentages, standard deviations of the sample's members in terms of the continuous education role in health culturing at King Saud University

\begin{tabular}{|c|c|c|c|c|c|c|c|c|}
\hline Item & Phrase & $\begin{array}{l}\text { Affirm. } \\
\text { Agree }\end{array}$ & Agree & $\begin{array}{l}\text { Don't } \\
\text { know }\end{array}$ & $\begin{array}{l}\text { Don't } \\
\text { Agree }\end{array}$ & $\begin{array}{c}\text { Affirm } \\
\text { Disagree }\end{array}$ & $\begin{array}{l}\text { Standard } \\
\text { Deviation }\end{array}$ & Sequence \\
\hline \multirow{2}{*}{1} & There is a specialized management for & 11 & 32 & 51 & 4 & 3 & \multirow{2}{*}{0.85} & \multirow{2}{*}{6} \\
\hline & Health culturing inside the University. & 10.89 & 31.68 & 50.5 & 3.96 & 2.97 & & \\
\hline 2 & $\begin{array}{l}\text { Doctors share in health scope in the } \\
\text { university in an effective manner. }\end{array}$ & 9 & 36 & 35 & 18 & 3 & 0.96 & 9 \\
\hline 3 & $\begin{array}{l}\text { Stickers are held in prominent places } \\
\text { about health culturing and their } \\
\text { protection methods. }\end{array}$ & $\begin{array}{c}16 \\
15.84\end{array}$ & $\begin{array}{c}39 \\
38.61\end{array}$ & $\begin{array}{c}26 \\
25.74\end{array}$ & $\begin{array}{c}14 \\
13.86\end{array}$ & $\begin{array}{c}6 \\
5.94\end{array}$ & 1.1 & 4 \\
\hline 4 & $\begin{array}{l}\text { University prepare programs to release } \\
\text { health awareness; seminars, workshops, } \\
\text { etc. }\end{array}$ & $\begin{array}{c}11 \\
10.8\end{array}$ & $\begin{array}{c}39 \\
38.6\end{array}$ & $\begin{array}{c}40 \\
39.6\end{array}$ & $\begin{array}{c}8 \\
7.92\end{array}$ & $\begin{array}{c}3 \\
2.97\end{array}$ & 0.9 & 3 \\
\hline 5 & $\begin{array}{l}\text { Publishing of health culturing activities } \\
\text { is sufficient inside the university. }\end{array}$ & $\begin{array}{l}10 \\
9.9\end{array}$ & 22 & $\begin{array}{c}30 \\
29.7\end{array}$ & $\begin{array}{c}29 \\
28.71\end{array}$ & $\begin{array}{c}10 \\
9.9\end{array}$ & 1.14 & 19 \\
\hline 6 & $\begin{array}{l}\text { University contributes in releasing health } \\
\text { awareness in terms of chronic diseases }\end{array}$ & $\begin{array}{c}11 \\
10.89\end{array}$ & $\begin{array}{c}36 \\
35.64\end{array}$ & $\begin{array}{c}32 \\
31.68\end{array}$ & $\begin{array}{c}21 \\
20.79\end{array}$ & $\begin{array}{c}1 \\
0.99\end{array}$ & 0.96 & 7 \\
\hline
\end{tabular}




\begin{tabular}{|c|c|c|c|c|c|c|c|c|}
\hline 7 & $\begin{array}{l}\text { University contributes in health culturing } \\
\text { in terms of healthy nutrition. }\end{array}$ & 11 & 42 & 32 & 13 & 3 & 0.95 & 4 \\
\hline 8 & $\begin{array}{l}\text { University has an effective role in health } \\
\text { culturing - reproductive heath }\end{array}$ & $\begin{array}{c}9 \\
8.91\end{array}$ & $\begin{array}{c}23 \\
22.77\end{array}$ & $\begin{array}{c}44 \\
43.56\end{array}$ & $\begin{array}{c}19 \\
18.81\end{array}$ & $\begin{array}{c}6 \\
5.94\end{array}$ & 1.01 & 17 \\
\hline 9 & $\begin{array}{l}\text { University flyers in health awareness are } \\
\text { sufficient. }\end{array}$ & $\begin{array}{l}10 \\
9.9\end{array}$ & $\begin{array}{c}31 \\
30.69\end{array}$ & $\begin{array}{c}40 \\
39.6\end{array}$ & $\begin{array}{c}14 \\
13.86\end{array}$ & $\begin{array}{c}6 \\
5.94\end{array}$ & 1.01 & 12 \\
\hline 10 & $\begin{array}{l}\text { Medical clinics in the university conduct } \\
\text { awareness releases on diseases' early } \\
\text { diagnosis }\end{array}$ & $\begin{array}{r}10 \\
9.9\end{array}$ & $\begin{array}{c}31 \\
30.69\end{array}$ & $\begin{array}{c}36 \\
35.64\end{array}$ & $\begin{array}{c}22 \\
21.78\end{array}$ & $\begin{array}{c}2 \\
1.98\end{array}$ & 0.97 & 12 \\
\hline 11 & $\begin{array}{l}\text { University holds regular courses about } \\
\text { First Aid }\end{array}$ & $\begin{array}{c}12 \\
11.88\end{array}$ & $\begin{array}{c}24 \\
23.76\end{array}$ & $\begin{array}{c}45 \\
44.55\end{array}$ & $\begin{array}{c}16 \\
15.84\end{array}$ & $\begin{array}{c}4 \\
3.96\end{array}$ & 0.99 & 15 \\
\hline 12 & University supplies health culturing tools & $\begin{array}{l}10 \\
9.9\end{array}$ & $\begin{array}{c}26 \\
25.74\end{array}$ & $\begin{array}{c}50 \\
49.5\end{array}$ & $\begin{array}{c}9 \\
8.91\end{array}$ & $\begin{array}{c}6 \\
5.94\end{array}$ & 0.96 & 12 \\
\hline 13 & $\begin{array}{l}\text { Places to hold courses for health } \\
\text { culturing are available. }\end{array}$ & $\begin{array}{c}8 \\
7.92\end{array}$ & $\begin{array}{c}25 \\
24.75\end{array}$ & $\begin{array}{c}59 \\
58.42\end{array}$ & $\begin{array}{c}7 \\
6.93\end{array}$ & $\begin{array}{c}2 \\
1.98\end{array}$ & 0.79 & 9 \\
\hline 14 & $\begin{array}{l}\text { University works to set out dates and } \\
\text { times of courses that suit students. }\end{array}$ & 9 & 19 & 48 & 16 & 9 & 1.03 & 18 \\
\hline 15 & $\begin{array}{l}\text { There is effective participation between } \\
\text { university and community individuals in } \\
\text { terms of health culture }\end{array}$ & $\begin{array}{c}7 \\
6.93\end{array}$ & $\begin{array}{c}27 \\
26.73\end{array}$ & $\begin{array}{c}61 \\
60.4\end{array}$ & $\begin{array}{c}5 \\
4.95\end{array}$ & $\begin{array}{c}1 \\
0.99\end{array}$ & 0.72 & 8 \\
\hline 16 & $\begin{array}{l}\text { University conducts health culturing } \\
\text { lectures in schools, companies, villages, } \\
\text { etc. }\end{array}$ & $\begin{array}{c}6 \\
5.94\end{array}$ & $\begin{array}{c}21 \\
20.79\end{array}$ & $\begin{array}{c}62 \\
61.39\end{array}$ & $\begin{array}{c}9 \\
8.91\end{array}$ & $\begin{array}{c}3 \\
2.97\end{array}$ & 0.79 & 16 \\
\hline 17 & $\begin{array}{l}\text { University assign campaigns to release } \\
\text { health awareness in surrounding zones. }\end{array}$ & $\begin{array}{l}10 \\
9.9\end{array}$ & $\begin{array}{c}18 \\
17.82\end{array}$ & $\begin{array}{c}66 \\
65.35\end{array}$ & $\begin{array}{c}6 \\
5.94\end{array}$ & $\begin{array}{c}1 \\
0.99\end{array}$ & 0.77 & 9 \\
\hline 18 & $\begin{array}{l}\text { University has programs to promote } \\
\text { health awareness in smoking damages }\end{array}$ & $\begin{array}{c}14 \\
13.86\end{array}$ & $\begin{array}{c}39 \\
38.61\end{array}$ & $\begin{array}{c}38 \\
37.62\end{array}$ & $\begin{array}{c}9 \\
8.91\end{array}$ & $\begin{array}{c}1 \\
0.99\end{array}$ & 0.88 & 1 \\
\hline 19 & $\begin{array}{l}\text { Univ. Holds programs to develop Health } \\
\text { Awareness of drugs }\end{array}$ & 13 & 38 & 42 & 7 & 1 & 0.84 & 2 \\
\hline & General Average & & & & & & 0.93 & \\
\hline
\end{tabular}

It is obvious from the results in Table 3 that the sample's majority does not know about health culturing programs presented at the University. Those who do not know such programs are rated at $43.61 \%$ out of study sample, while approvals are rated at $39.81 \%$ of study sample individuals. Disapprovals are rated at $16.51 \%$, which offers an indication that the programs presented by the University for post studies students in health culturing are considered good. But failure main reason is attributed to weak publishing and advertising circulated on such programs.

\subsection{Question \# (4): What Are the Challenges Facing the Continuous Education Programs at King Saud University?}

To answer this question, frequencies, percentages, and standard deviations of the rates of Continuous Education Center's challenges (expenditure, participation and attendance, management) from the perceptions of its Directors were calculated and presented in Table 4 and Table 5 below: 


\subsubsection{Expenditure}

Table 4. Frequencies, percentages, standard deviations of the continuous education center's expenditure from the perceptions of its directors

\begin{tabular}{|c|c|c|c|c|c|c|c|c|c|}
\hline Item & Phrase & & $\begin{array}{l}\text { Affirm } \\
\text { Agree }\end{array}$ & Agree & $\begin{array}{l}\text { Don't } \\
\text { know }\end{array}$ & $\begin{array}{l}\text { Don't } \\
\text { Agree }\end{array}$ & $\begin{array}{c}\text { Affirm } \\
\text { Disagree }\end{array}$ & $\begin{array}{c}\text { Standard } \\
\text { Deviation }\end{array}$ & Frequency \\
\hline 1 & $\begin{array}{l}\text { Employees in charge believe that } \\
\text { investment income used in financing } \\
\text { continuous programs is low }\end{array}$ & $\%$ & $\begin{array}{c}2 \\
22.22\end{array}$ & $\begin{array}{c}3 \\
33.33\end{array}$ & $\begin{array}{l}0 \\
0\end{array}$ & $\begin{array}{c}3 \\
33.33\end{array}$ & $\begin{array}{c}1 \\
11.11\end{array}$ & 1.48 & 4 \\
\hline 2 & $\begin{array}{l}\text { The center depends on self financing } \\
\text { through attendants contributions to } \\
\text { produce its programs and seminars. }\end{array}$ & $\%$ & $\begin{array}{l}0 \\
0\end{array}$ & $\begin{array}{c}4 \\
44.44\end{array}$ & $\begin{array}{c}2 \\
22.22\end{array}$ & $\begin{array}{c}2 \\
22.22\end{array}$ & $\begin{array}{c}1 \\
11.11\end{array}$ & 1.12 & 5 \\
\hline 3 & $\begin{array}{l}\text { The center depends on fixed financing } \\
\text { by the University to finance education } \\
\text { programs and seminars. }\end{array}$ & $\%$ & $\begin{array}{l}0 \\
0\end{array}$ & $\begin{array}{c}4 \\
44.44\end{array}$ & $\begin{array}{c}2 \\
22.22\end{array}$ & $\begin{array}{c}1 \\
11.11\end{array}$ & $\begin{array}{c}2 \\
22.22\end{array}$ & 1.27 & 6 \\
\hline 4 & $\begin{array}{l}\text { Expenditure on continuous education } \\
\text { programs is considered as a social } \\
\text { service. }\end{array}$ & $\%$ & $\begin{array}{c}2 \\
22.22\end{array}$ & $\begin{array}{c}6 \\
66.67\end{array}$ & $\begin{array}{l}0 \\
0\end{array}$ & $\begin{array}{c}1 \\
11.11\end{array}$ & $\begin{array}{l}0 \\
0\end{array}$ & 0.87 & 1 \\
\hline 5 & $\begin{array}{l}\text { Depending on government financing of } \\
\text { continuous education programs reduces } \\
\text { other financing sources. }\end{array}$ & $\%$ & $\begin{array}{c}2 \\
22.22\end{array}$ & $\begin{array}{c}4 \\
44.44\end{array}$ & $\begin{array}{l}0 \\
0\end{array}$ & $\begin{array}{c}2 \\
22.22\end{array}$ & $\begin{array}{c}1 \\
11.11\end{array}$ & 1.42 & 2 \\
\hline 6 & $\begin{array}{l}\text { Continuous education center applies } \\
\text { standards as guidelines to assess } \\
\text { expenses of continuous education } \\
\text { programs. }\end{array}$ & $\%$ & $\begin{array}{l}0 \\
0\end{array}$ & $\begin{array}{c}6 \\
66.67\end{array}$ & $\begin{array}{c}1 \\
11.11\end{array}$ & $\begin{array}{c}1 \\
11.11\end{array}$ & $\begin{array}{c}1 \\
11.11\end{array}$ & 1.12 & 3 \\
\hline & General Average & & & & & & & 1.21 & \\
\hline
\end{tabular}

One of the challenges that face the continuous education center at King Saud University is expenditure. Table 4 shows that the education centers directors' main challenge that is facing the implementation of continuous education programs is the poor financing support, and thus the center depends on its self financing and limited financing from the University. They also agree that such programs offer service to the community. The Directors are also agreed on the fact that such centers are directed by fixed standards to assess the expenses connected to their programs, and if governmental financing is made available then this shall reduce their counting on financing resources.

Moreover, Table 4 shows that the major values of the standard deviation of expenditure sector are limited to 0.87 , 1.48. The least standard deviation of the phrase (expenditure on educational programs is considered as a social service), whilst the largest value of the standard deviation for the phrase (The people in charge see that the investment revenue of financing the continuous education programs is minor).

\subsubsection{Participation and Attendance}

Table 5. Frequencies, percentages, standard deviations of the continuous education center's participation and attendance from the perceptions of its directors

\begin{tabular}{|c|c|c|c|c|c|c|c|c|c|c|}
\hline Item & Phrase & & $\begin{array}{l}\text { Affirm. } \\
\text { Agree }\end{array}$ & Agree & $\begin{array}{l}\text { Don't } \\
\text { know }\end{array}$ & $\begin{array}{l}\text { Don't } \\
\text { agree }\end{array}$ & $\begin{array}{c}\text { Affirm. } \\
\text { Disagree }\end{array}$ & SMA & $\begin{array}{l}\text { Standard } \\
\text { Deviation }\end{array}$ & Frequency \\
\hline 1 & $\begin{array}{l}\text { Time of presenting continuous } \\
\text { education programs is suitable } \\
\text { for students. }\end{array}$ & $\%$ & $\begin{array}{c}1 \\
11.11\end{array}$ & $\begin{array}{c}4 \\
44.44\end{array}$ & $\begin{array}{c}3 \\
33.33\end{array}$ & $\begin{array}{l}0 \\
0\end{array}$ & $\begin{array}{c}1 \\
11.11\end{array}$ & 3.44 & 1.13 & 1 \\
\hline 2 & $\begin{array}{l}\text { Students and targeted categories } \\
\text { rates are within expected limits - } \\
\text { satisfactory. }\end{array}$ & $\%$ & 1 & 2 & 1 & 5 & 0 & 2.89 & 1.17 & 4 \\
\hline 3 & $\begin{array}{l}\text { Teaching team participation rate } \\
\text { in controlling programs and } \\
\text { seminars is satisfactory. }\end{array}$ & $\%$ & 0 & 5 & 2 & 1 & 1 & 3.22 & 1.09 & 3 \\
\hline
\end{tabular}




\begin{tabular}{|c|c|c|c|c|c|c|c|c|c|c|}
\hline 4 & $\begin{array}{l}\text { Heavy burdens over teaching } \\
\text { team affect negatively on their } \\
\text { participation in continuous } \\
\text { education programs. }\end{array}$ & $\%$ & 0 & 6 & 1 & 1 & 1 & 3.33 & 1.12 & 2 \\
\hline 5 & General Average & $\%$ & & & & & & 3.22 & 1.13 & \\
\hline
\end{tabular}

Table 5 results about the participation and attendance at continuous education programs showed that the center's directors agreed on the suitability of the programs' presentation times, and the attendants of such programs were within the expected limits in general. Also satisfactory percentage was considered. As to teaching committee and their participation in presenting such programs the approvals were rated at $52.77 \%$ whilst those of centers directors participations were $27.77 \%$.However, $19.44 \%$ of the study sample stated that they do not know the suitability extent as to presenting continuous education programs addressed to students.

On the other hand, Phrase (Students attendance and targeted categories' rates are within expected limits (satisfactory) occupied the fourth and last degree of frequencies. This result may be attributed to the fact that the programs are not in line with students' needs and wishes. Moreover, standard deviation values showed that the majority of standard deviation values as to phrases of participation and attendance sector are limited between $1.09,1.17$. The least standard deviation of phrase (teaching team participation and attendance in addressing seminars and programs was satisfactory), the highest value of standard deviation of phrase (students and targeted categories attendance is within expected rates (within satisfactory limits)

\subsubsection{Management}

The Questionnaire directed to sample selected out of the continuous education centers' managers in the university showed about $50 \%$ approvals of the study sample to ensure the availability of:

- Quality of scientific seminars organization

- $\quad$ Buildings and fittings quality

- $\quad$ Programs contexts

- Intensives activities to encourage the students for attendance,

- $\quad$ Setting out awareness campaigns as to continuous education programs.

- Availability of declared strategy by the university works to facilitate determining programs' types and targeted categories,

- $\quad$ flexibility in rules to facilitate programs' organizing and concluding issues

- $\quad$ Stability in University Supreme Management priorities.

- $\quad$ Suitability of teaching committee members rehabilitation level,

- Availability of internal coordination among the center management and teaching committee members and clarity of group work concept.

- Centers fulfillment for students and teacher's needs through developing community service sites in the internet \& social interconnection sites.

$25.92 \%$ of the centers' managers who participated in the study declared their disapproval, especially to what belongs to clarity of the university strategy on community service programs and declaring them in a way to facilitate defining programs' types and targeted categories, and the presence of internal coordination between centers' managers and teaching committee members.

The domain's outcomes refer to $24.57 \%$ out of participating centers' directors in the study stated their ignorance as to many points included in this domain, especially

- Availability or otherwise of incentives which encourage the students to attend the center programs,

- Whether the program contents are satisfactory or otherwise.

- Whether there is internal coordination with teaching members to address such programs

- Whether the programs and seminars reflect scientific sides for all specialties.

- $\quad$ Availability of buildings and fittings to conduct seminars.

- Whether there is awareness campaigns directed to the students to bring them acquainted to the center 
programs.

- Moreover, What relating to stability extent, priorities and domains of the University, flexibility of the university rules which facilitate concluding such programs and seminars in these centers, group work concept clarity, and if the students and teacher requirements are fulfilled on the internet and social interconnection sites.

From reviewing the standard deviation values Table 5, it is obvious that most of standard deviation values of management sector are limited between 0.93-1.36. The least standard deviation was of the phrase (availability of incentives to encourage the students to attend such programs), while the highest standard deviation value was directed to phrase (there is clear strategy declared by the university on community service programs which facilitate programs' types and targeted categories' definition).

\subsection{Summary}

To sum up; the current study results showed that:

- Continuous education programs presented in religious awareness development do not contribute sufficiently in developing them.

- Continuous education programs have favorable role in community's social culturing.

- Continuous education programs contribute moderately, in community's health culturing.

- $\quad$ People in charge agree that the investment revenue in financing continuous continuous education programs is minor as well as financing offered by the University.

- Students attendance and targeted categories rates in continuous education programs are considered minor

- $\quad$ The people in charge view on the unavailability of suitable buildings, program context, students' incentives, rules and bylaws is considered challenges as to program role process.

\subsection{Recommendations}

In light of the results of this study the researchers recommend the following:

1) Paying attention to present more continuous education programs of concern as to individuals needs through cooperation with the research center in the University to perform survey studies targeted to define the individuals needs in terms of religious, social and health issues.

2) Benefiting of the teaching committee members in all sections and faculties to address the most possible and variable programs; religious, social and health. The foregoing could be achieved through allocating single day whereas the teaching committee members are free to work in the continuous education center.

i. Realizing partnership between the community service center and all governmental sectors therein to benefit of specialized human capacities located in such sectors.

ii. Establishing media committee reporting to continuous education center engaged in medial and publishing mission for the center programs routing all traditional and modern channels.

iii. Establishing private management responsible to follow up and assess programs and activities carried out by the continuous education center.

iv. Allocating special and independent budget for the continuous education center and set out them under the disposal of the center personnel without being connected to the University budget.

\section{References}

Abdel-Majeed, F. (2012). Planning the food meals for normal persons and those of special needs. Saudi Arabia: Al Zahraa house for publishing and distribution, Al Riyadh.

Al Miqdadi, K. (2006). Environmental education. Denmark: Open Arab Academy-Environment management in Denmark Press.

Al Rawwaf, H. (2014). Education and relationship with opportunities to allocate job. Egypt: Modern Education Press.

Alqudah, M., Johnson, M., Cowin, L., \& George, A. (2014). An innovative fever management education program for parents, Caregivers, and Emergency Nurses. Advanced Emergency Nursing Journal, 36(1), 52-61. https://doi.org/10.1097/TME.0000000000000004

Ammar, M. (2009). Quality education college-Manofiah University in offering services for the local community. 
Egyptian University Education Studies, 20.

Belonozhko, M., \& Khitu, E. (2008). On the characteristics of Higher Education for Adults. Russian Education and Society Journal, 50(3), 57-63. https://doi.org/10.2753/RES1060-9393500305

Emmanuel, B., Felicia, D., \& Vera, G. (2013). Information literacy programs in University Libraries: A case study. Libri Journal, 63(4).

Ghareeb, M. (2005). Religious programs role in the satellites' Arab channels in religious culturing of Universities students. Egyptian Journal for public view researches, 6(2).

Hammer, K. (2014). Global Rate of Adult literacy. Retrieved from $\mathrm{http} / /$ :www.Theglobeandmail.com/news/world/global-rate-of-adult-literacy

Ibrahim, A. (2013). Continuous education and old people teaching. Al Azhari Leader University Journal, Sudan center for scientific research, 11(3).

Kumar, A. (2012). Philosophical Background of Adult and Lifelong learning" Participatory lifelong learning and information and communication technology, Jawaharlal Nehru University New Delhi. Education-school of social sciences Journal, 12(2).

Le, Q., Terry, D., \& Woodroffe, J. (2013). Current Programs and future needs in health literacy for older people. Journal of Consumer Health on the Internet, 17(3), 369-388. https://doi.org/10.1080/15398285.2013.833449

Loos, A. (2013). Evaluation of social media use at health education organization: A Case study of health literacy. Missouri International Electronic Journal of health education. Retrieved from http//:www.Healtheducation.edu.U.K

Putnam, R. (2001). Social capital: Measurement and consequences. In J. Helliwell (Ed.), The contribution of human and social capital to sustained economic growth and well-being. Quebec: OECD and Human resources.

Rashad, N. (2000). Health education and safety. Al Maaref Journal, 1(2).

Rawwaf, H. (2008). Universities role to eliminate the illiteracy on the light of some countries expertise. Annual conference proceedings organized by Old people education center, Eian Sham University Egypt, 17/8/2008.

Robin, K. (2000). Programs that work. FRESH project: Fitness, Recreation and Education for senior health. Journal of park and recreation Administration, 10(2).

Saadat, K. (2004). The community service center respond extend in the technique college - Al Ahsaa' for the community and individuals needs from the point of view of teaching committee in the college。 Muta Journal for Researches and Studies, 19(1).

Said, M. (1990). Community service University programs. Faculty of Education Journal, Zaqazeeq University, 11(3).

\section{Copyrights}

Copyright for this article is retained by the author(s), with first publication rights granted to the journal.

This is an open-access article distributed under the terms and conditions of the Creative Commons Attribution license (http://creativecommons.org/licenses/by/4.0/). 